Article

\title{
Cardiac Effects of a Rowing Training Program in Breast Cancer Survivors
}

\author{
Juan Gavala-González ${ }^{1}\left(\mathbb{0}\right.$, Ismael Gálvez-Fernández ${ }^{2, *} *$, Pere Mercadé-Melé ${ }^{3}(\mathbb{C})$ \\ and José Carlos Fernández-García ${ }^{2}$ (D)
}

1 Department of Physical Education and Sports, University of Seville, 41013 Seville, Spain; jgavala@us.es

2 Department of Didactics of Languages, Arts and Sport, University of Malaga, Andalucía-Tech, IBIMA, 29010 Malaga, Spain; jcfg@uma.es

3 Department of Statistics and Econometrics, University of Malaga, Andalucía-Tech, 29010 Malaga, Spain; pmercade@uma.es

* Correspondence: ismaelgalf@uma.es

Citation: Gavala-González, J.;

Gálvez-Fernández, I.; Mercadé-Melé,

P.; Fernández-García, J.C. Cardiac

Effects of a Rowing Training Program

in Breast Cancer Survivors.

Sustainability 2021, 13, 6805. https://

doi.org/10.3390/su13126805

Academic Editor: José Carmelo

Adsuar Sala

Received: 14 May 2021

Accepted: 11 June 2021

Published: 16 June 2021

Publisher's Note: MDPI stays neutral with regard to jurisdictional claims in published maps and institutional affiliations.

Copyright: (c) 2021 by the authors. Licensee MDPI, Basel, Switzerland. This article is an open access article distributed under the terms and conditions of the Creative Commons Attribution (CC BY) license (https:// creativecommons.org/licenses/by/ $4.0 /)$

\begin{abstract}
The aim of this study was to determine whether a rowing training program could improve cardiac function in women $(n=28)$ with the mean age of $52.30 \pm 3.78$ years who survived breast cancer (stage 1: $4.55 \%$; 2: 36.36\%; 3: 54.54\%; and 4: 4.55\%) diagnosed $4.68 \pm 3.00$ years previously and underwent subsequent surgery (preservation: 56.52\%; total mastectomy: 39.13\%; and double mastectomy: $4.35 \%$ ). Participants completed a 12-week training program consisting of three weekly sessions lasting 60-90 min with a progressive intensity increase according to the Börg scale. The assessments performed were blood pressure and pulse measurements both at rest and after performing the six-minute walk test to collect data on cardiac behavior and aerobic performance. The results showed statistically significant differences in cardiovascular system efficiency measured on the basis of heart rate both before $(-12.63 \pm 14.68 \mathrm{bpm})$ and after the six-minute walk test $(-11.46 \pm 28.39 \mathrm{bpm})$, increase in the distance achieved in the aerobic endurance test $(51.56 \pm 48.26 \mathrm{~m})$ as well as decrease in diastolic $(-13.6 \pm 7.85 \mathrm{~mm} \mathrm{Hg})$ and systolic $(-6.60 \pm 9.10 \mathrm{~mm} \mathrm{Hg})$ blood pressure. These results suggest that rowing training programs could be a strategy to consider in this population for the benefits observed in heart rate, blood pressure and aerobic performance, which would lead to improved general health and quality of life.
\end{abstract}

Keywords: breast cancer survivor; rowing training; physical activity; training effects

\section{Introduction}

Breast cancer (BC) is the most common cancer in the world, affecting mostly women [1]. According to the International Agency for Research on Cancer [2], 4\% of the worldwide female population has suffered or will suffer from BC and it is estimated that this will double in the coming decades. Only a few years ago, receiving a diagnosis of BC was, at best, equivalent to being unable to use the upper limbs [3] and, at worst, it was associated with high mortality rates [4]. Today, BC has a survival rate of over $75 \%$ in the first five years after surgery. This high survival rate is largely due to early diagnosis, effective treatment and adopting an active lifestyle [5,6].

Various studies have proven that engaging in physical activity improves quality of life [7], producing improvements in aerobic capacity and muscle strength, increasing muscle mass and strength while improving the functionality of the upper extremities [8-11]. In addition, physical activity decreases the duration and intensity of fatigue [12] as well as reduces anxiety and depression [13].

Most of the studies consulted [14-17] affirm that physical activity also contributes to improving physical condition and quality of life in BC survivors [12,18-22] while decreasing the risk of $\mathrm{BC}$ recurrence [11,23-27]. At the same time, exercise plays an important role in preventing or delaying the onset of other diseases in these individuals $[23,26,28,29]$ and 
is a key element in recovery from BC and its aftereffects, although some studies [28-30] indicate that not all programs produce improvements; in addition, according to Leischik, diseases such as cardiomyopathy can also develop [31].

Considering that physical activity seems to play an important role in improving quality of life in $\mathrm{BC}$ survivors, it is surprising that there is no scientific evidence on the prescription and characteristics of the most suitable exercise for this population [32]. The American College of Sports Medicine and the World Health Organization have recommended that both the general population and cancer survivors should engage in 150 min of moderate aerobic activity or $75 \mathrm{~min}$ of vigorous aerobic activity per week and two days of resistance training per week [33].

In a thorough review of our subject matter, we observed that the existing literature on physical activity and BC is scarce, but in the case of rowing and BC, it is practically nonexistent. For this reason, we believe that our study may represent progress in prescribing healthy exercise for this population and disease. It should be noted that not long ago, physical activity was contraindicated for BC survivors, especially if it involved mobilizing the upper limbs, as it was thought that physical activity involving the upper limbs caused lymphedema or chronic swelling of the arm due to the removal and/or exposure of the lymph nodes in the axilla. It was then argued that the mobilization of these body parts caused an increase in blood flow in the area and therefore a greater production of lymph, which, due to poor drainage, would accumulate in these extremities [34]. McKenzie [35] was the first to develop therapies that involved mobilization of the upper limbs and, more specifically, he recommended paddling in a dragon boat because it is a strenuous, repetitive upper body activity that projects a visible message to all people with BC. It is non-weightbearing and is therefore associated with a lower risk of injury than weight-dependent activities such as running. According to McKenzie, dragon boat paddling "carried out in an appropriate way" increases psychological improvements [35]. According to Stefani et al. (2015), we must specify that dragon boat paddling is not suitable for everyone because it is a very strenuous exercise [34] in addition to using positions that are difficult to adopt for BCS since those that suffered from $\mathrm{BC}$ have neither as much flexibility in the upper limbs as to lift the attacking hand above the head nor as much force in the pulling hand due to surgery.

McKenzie's experiment had a great impact not only for the daring to prescribe physical exercise, but also because he took advantage of several dragon boat competitions to show the world his Breast Cancer Survivor team which, together with the conclusions of his studies regarding the improvement in quality of life of these women, led to a global movement of hundreds of women around the world practicing this sport [36]. This resulted in various studies on the binomial "dragon boat" and "breast cancer", many of which focus on psychological aspects [37-39]. Studies on the effects of this practice on the physical condition of these women, such as improvements in mobility [40], increased strength in different body segments [41,42], as well as improvements in quality of life, are still scarce [18,43-46].

Our study subjects engaged in the sport of rowing as an exercise prescription. This activity was chosen because it involves muscles of both the lower and upper extremities [47] and almost all the muscles of the body [48]. According to the classification of RomeroBarquero, rowing is a sport that, when performed frequently, is beneficial for adults, preventing cardiovascular risks and death [45]. While dragon boat paddling is asymmetric and involves difficult movements and forced postures, rowing consists of a simultaneous contraction of the upper and lower body muscles followed by a relaxation phase [46] and is a cyclical and symmetrical sport. It is cyclical because the motor pattern is repeated from the beginning to the end of the activity [49] and symmetrical because the limbs (upper and lower, right and left) are involved simultaneously and similarly. Furthermore, unlike dragon boat paddling, rowing uses all the muscles of the body. A much longer paddle is used and a lever is attached to the boat, which makes rowing training less vigorous than dragon boat paddling since all these elements allow us to achieve higher speeds than those reached in a dragon boat with a lower effort. 
According to the National Cancer Institute, certain treatments can damage the heart and the circulatory system leading to a series of side effects, such as hypertension, abnormal heart rhythm and heart failure, which are generally caused or exacerbated by chemotherapy and radiotherapy [50]. No studies currently exist that analyze how rowing affects heart function and blood pressure in BC survivors, but there are several articles showing that physical exercise improves these functions [37,51-56]. Notable among them is the study by Stefani et al. [51] which reports that BC survivors who received chemotherapy treatment experienced a significant improvement in diastolic function measurements after four years of dragon boat training, increasing by $2.5 \mathrm{~cm} / \mathrm{s}$. These results support the potential positive role of physical exercise on myocardial function in BC survivors. In addition, the work of Serra et al. [52] indicated that after an aerobic training program, a 5\% reduction was achieved in both systolic and diastolic blood pressure in BC survivors.

The aim of this study was to understand how a rowing-based training program could affect heart function as assessed by systolic and diastolic blood pressure as well as by heart rate after an aerobic test in $\mathrm{BC}$ survivors.

\section{Materials and Methods}

\subsection{Design and Participants}

The participants $(n=28)$ had an average age of 52.30 (SD: \pm 3.78$)$ years and were recruited provided they had overcome BC (stage 1: $4.55 \%$; 2: 36.36\%; 3: $54.54 \%$; and 4: $4.55 \%$ ) diagnosed 4.58 (SD: \pm 3.00 ) years previously and had undergone a subsequent surgery (preservation: $56.52 \%$; total mastectomy: $39.13 \%$; and double mastectomy: $4.35 \%$ ); $93.3 \%$ of them received chemotherapy and radiotherapy treatment and $100 \%$ of the participants continued with their hormonal treatment based on tamoxifen (Table 1).

Table 1. Characteristics of the sample regarding breast cancer.

\begin{tabular}{|c|c|c|c|c|c|c|c|}
\hline Age (Years) & Years from Diagnosis & Stage & $\%$ & Surgery & $\%$ & Treatment & $\%$ \\
\hline \multirow{4}{*}{$52.30 \pm 3.78$} & \multirow{4}{*}{$4.68 \pm 3.00$} & 1 & 4.55 & Preservation & 56.52 & \multirow{2}{*}{ Chemotherapy } & \multirow{2}{*}{93.3} \\
\hline & & 2 & 36.36 & Total mastectomy & 39.13 & & \\
\hline & & 3 & 54.54 & \multirow{2}{*}{ Double mastectomy } & \multirow{2}{*}{4.35} & \multirow{2}{*}{ Radiotherapy } & \multirow{2}{*}{93.3} \\
\hline & & 4 & 4.55 & & & & \\
\hline
\end{tabular}

Prior to the start of the project, a meeting was organized between the project coordinator and the participants where the objectives and nature of the study were explained. It was made clear that the ethical considerations of sport and exercise science research [57] would be followed at all times, as well as the principles included in the Declaration of Helsinki [58] which defines ethical guidelines for research on human subjects. The University of Malaga provided the registered identification number for the Ethics Committee: $65-2020-\mathrm{H}$. All the participants provided written informed consent. At all times during the study both before, during and after the intervention, we acted in accordance with the provisions of Organic Law 3/2018 of December 5 on Protection of Personal Data and Guarantee of Digital Rights with respect to the protection of personal data under Spanish legislation.

\subsection{Instruments}

We used the six-minute walk test [59] which is a valid and reliable test to assess a subject's cardiorespiratory fitness by measuring the maximum distance the subject can walk for six minutes on a flat surface. At the same time, heart rate per minute was monitored immediately before and after completing the test through a Polar H7 chest strap (placed before starting the test) that transmitted this signal to the POLAR tablet application. An Omron M6 Comfort IT upper arm blood pressure monitor was used to take blood pressure measurements, recording systolic and diastolic pressure and heart rate per minute. 
The training program was held at the facilities of Real Club Mediterráneo in Malaga. The training was divided into three parts.

1. Warm-up: warm-up, mobility, proprioceptive and postural control exercises, all carried out in a multipurpose room.

2. The main part was carried out in the Mediterranean Sea near the port of Malaga. The boats used were llauts, fixed-bench boats typical of the Spanish Mediterranean. These boats have eight oarsmen and a coxswain or skipper. Each oarsman applies force on a single oar attached to the boat through an oarlock and a ring using both hands simultaneously [60].

3. Low-intensity stretching.

\subsection{Procedure}

Each participant was notified in advance of the day on which the initial measurements and assessments would take place. These were carried out in what would be their usual place for subsequent training. Before the assessments, the participants were invited to a conference room where they met the evaluators and were given a brief introduction to the benefits of rowing. Following the presentation and after a five-minute rest period, each participant's blood pressure was measured in the arm contralateral to the operated side. The blood pressure monitor was reapplied two minutes later and a second measurement was taken. After completing this test, with the participant barefoot and in light clothing, anthropometric evaluation of weight and height was conducted respecting the Frankfurt plane. Next, a Polar H7 chest strap was given to each participant to be fitted according to the manufacturer's specifications and it was tested to ensure that it emitted a signal to the POLAR application installed in an electronic tablet. Finally, each subject performed the six-minute walk test in a large area, free of objects and with a tape measure extended between two cones to indicate the starting point and the place where they should turn around and continue with the test.

After the initial tests, the participants underwent a 12-week rowing program. Each week consisted of three 60-90 min training sessions, which were divided into warmup (10-15 min, of which $50 \%$ was dry and the other $50 \%$ in water) and the main part (40-60 min) based on technical exercises, combined with exercises of playing with the strokes (aerobic exercises) which were supervised by a rowing coach who ensured proper execution of the tasks to prevent injuries and monitored the intensity of the sessions. Finally, the training sessions end with flexibility exercises, with the aim of relaxing the muscles (10-15 min). Training attendance was recorded each day and the participants who did not attend at least $90 \%$ of the sessions were excluded from the study.

The training period was divided into three stages, as shown in Table 2. The intensity was progressively increased through the subjective perceived exertion rating of the participants [61]. Upon completion of the 12-week training period, all the subjects who completed the program were reassessed using the same tests and procedures used in the initial evaluation.

Table 2. Design of the prescribed exercise program.

\begin{tabular}{cc}
\hline Stage & Content \\
\hline $\begin{array}{c}\text { Initial } \\
\text { (four weeks) }\end{array}$ & $\begin{array}{c}\text { Warm-up with mobility exercises, proprioceptive exercises and postural control exercises, with } \\
\text { rowing training as the main part and stretching exercises as the final part. Intensity according to the } \\
\text { Börg rating of perceived exertion: 5-6. }\end{array}$ \\
$\begin{array}{c}\text { Intermediate } \\
\text { (four weeks) }\end{array}$ & $\begin{array}{c}\text { Warm-up with mobility exercises, proprioceptive exercises and postural control exercises, with } \\
\text { rowing training as the main part and stretching exercises as the final part. Intensity according to the } \\
\text { Börg rating of perceived exertion: 6-7. }\end{array}$ \\
$\begin{array}{c}\text { Final } \\
\text { (four weeks) }\end{array}$ & $\begin{array}{r}\text { Warm-up with mobility exercises, proprioceptive exercises and postural control exercises, with } \\
\text { rowing training as the main part and stretching exercises as the final part. Intensity according to the } \\
\text { Börg rating of perceived exertion: 7-8. }\end{array}$ \\
\hline
\end{tabular}




\subsection{Data Analysis}

Data analyses were performed using the Statistical Package for Social Sciences, version 25 (IBM Corp., Armonk, NY, USA).

Before analyzing the statistically significant differences resulting from the rowing training, the normality of the study variables was tested using the Shapiro-Wilk test. Next, the differences between the means of each variable pre- and post-intervention were studied. Finally, parametric testing with the Student's $t$-test for related samples was undertaken to determine whether the differences were statistically significant using the probability left in the Student's $t$-test, that is, the $p$-value $(p)$. Cohen's $d$ for a paired samples $t$-test was also performed to analyze the size of the effects, where Cohen [61] defined small, medium and large effect sizes as $d=0.2,0.5$ and 0.8 , respectively. Thus, the $p$-value and the size of the effect were used to see if the differences were statistically significant and clinically relevant.

\section{Results}

Table 3 presents the analysis of the study variables before and after the rowing training program. To assess possible statistically significant differences, the Student's $t$-test for related data was performed. Significant improvement was found in all the variables after completion of the intervention. The variables diastolic blood pressure $($ diff $=$ post - pre $=$ $-13.6 \pm 8.02 ; t=-9.484 ; p=0.000)$, systolic blood pressure (diff $=$ post-pre $=-6.60 \pm 9.10$; $t=-3.971 ; p=0.000)$, starting heart rate on the six-minute walk test (diff $=$ post-pre $=$ $-12.63 \pm 14.68 ; t=-4.712 ; p=0.000)$, final heart rate on the six-minute walk test (diff $=$ post-pre $=-11.46 \pm 28.39 ; t=-2.212 ; p=0.035$ ) and distance on the six-minute walk test (diff $=$ post - pre $=51.56 \pm 48.26 ; t=5.852 ; p=0.000)$ showed significant differences between the pre- and post-training values. Regarding the effect size, Cohen's $d$ for paired samples was calculated, revealing that the differences, in addition to being statistically significant, were relevant as they presented values greater than 0.4 .

Table 3. Statistical analysis of the study variables. Mean \pm standard deviation; differences.

\begin{tabular}{|c|c|c|c|c|c|c|}
\hline Variables & Pre-Test & Post-Test & Diff = Post-Pre & Student's $t$ & Effect Size & $p$ \\
\hline $\begin{array}{l}\text { Diastolic blood pressure } \\
(\mathrm{mm} \mathrm{Hg})\end{array}$ & $124.40 \pm 15.21$ & $110.80 \pm 14.97$ & $-13.6 \pm 7.85$ & -9.484 & 1.73 & $0.000^{* * *}$ \\
\hline $\begin{array}{l}\text { Systolic blood pressure } \\
(\mathrm{mm} \mathrm{Hg})\end{array}$ & $82.13 \pm 10.37$ & $75.53 \pm 11.18$ & $-6.60 \pm 9.10$ & -3.971 & 0.73 & $0.000^{* * *}$ \\
\hline $\begin{array}{l}\text { Starting heart rate on the } \\
\text { six-minute walk test (bpm) }\end{array}$ & $98.43 \pm 16.72$ & $85.80 \pm 9.79$ & $-12.63 \pm 14.68$ & -4.712 & 0.86 & $0.000^{* * *}$ \\
\hline $\begin{array}{l}\text { Final heart rate on the } \\
\text { six-minute walk test (bpm) }\end{array}$ & $143.26 \pm 32.64$ & $131.80 \pm 18.62$ & $-11.46 \pm 28.39$ & -2.212 & 0.40 & $0.035^{* * *}$ \\
\hline $\begin{array}{l}\text { Distance on the six-minute } \\
\text { walk test }(\mathrm{m})\end{array}$ & $611.23 \pm 87.01$ & $662.80 \pm 85.82$ & $51.56 \pm 48.26$ & 5.852 & 1.07 & $0.000^{* * *}$ \\
\hline
\end{tabular}

Diff $=$ post-pre $=$ differences between the post-test and pre-test results; ${ }^{* * *} p<0.01$.

\section{Discussion}

The study of cancer in combination with exercise is relatively recent in sports science. Indeed, the first studies on the effects of physical activity in women with BC reported conclusions in the field of psychology [35]. Recently, new research has emerged, describing improvements in physical condition which has been manifested with a high degree of statistical significance in aerobic capacity with an improvement of around $9 \%$ in such a short space of time $[8,12,21,23,25]$ and an improvement in upper extremity function [9-11], the final effect of which was, as already pointed out by McKenzie, an improvement in the quality of life practiced in safe conditions and not presenting any injury as considered by this author in his research with dragon boat paddling $[9,10,14-17,32,35]$. 
Despite these scientific advances, some side effects of cancer treatments (chemotherapy and radiotherapy) have still not been sufficiently studied. Indeed, there is evidence of aggressiveness of these treatments and their effects on the heart and the cardiovascular system [50].

Until now, no scientific results have been available to support the use of rowing as an activity to improve cardiac function in BC survivors, although literature exists on cardiac function in BC survivors who engage in dragon boat training and other exercise modalities [37,51-56]. The most striking results of these studies are the significant improvement in diastolic function after four years of dragon boat training [51] together with the work of Serra et al. [52] whose findings revealed a 5\% reduction in systolic and diastolic blood pressure in female $\mathrm{BC}$ survivors after a 16-week resistance training program while our research obtained twice the reductions for these same variables, a total of $10 \%$ with four fewer weeks of treatment.

Unlike the studies mentioned above, our work presents some of the effects of rowing training (not dragon boat paddling). Interestingly, with a shorter training period than in previous studies (48/16 weeks), our results demonstrated a decrease in heart rate in the participants (both at rest and during exertion) by a mean of $12 \mathrm{bpm}$, which translated into an improvement in aerobic performance of $51.56 \pm 48.26 \mathrm{~m}$ on the six-minute walk test and reductions in blood pressure of $-13.6 \pm 7.85 \mathrm{~mm} \mathrm{Hg}$ in diastolic blood pressure and $-6.60 \pm 9.10 \mathrm{~mm} \mathrm{Hg}$ in systolic blood pressure. Lee's previous studies [56], although with a large sample of subjects, only constitute a descriptive study about the relationships between heart rate at rest and blood pressure. Fong [37,40] did not include aerobic work as they used qigong as a physical activity in which the upper extremities are used in a very relaxed and controlled way. Finally, Leischik [31] showed evidence between cardiorespiratory fitness and cardiovascular health, although this association was not based on a longitudinal study as in this investigation.

\section{Conclusions}

Rowing training programs may be a strategy to consider for female BC survivors not only because of the psychological and physical fitness benefits, but also because of the benefits found in heart rate, blood pressure and aerobic performance that lead to better overall health and quality of life.

From a cardiovascular perspective, this study suggests that rowing training may be more advisable than dragon boat training for women who survived BC. The results achieved showed greater improvements than those obtained in previous research. These improvements were also attained within a shorter period of time compared to similar physical activity programs.

Author Contributions: I.G.-F. and J.G.-G. conceived and conceptualized the study. I.G.-F. and P.M.M. collected and analyzed the data. I.G.-F., J.C.F.-G., J.G.-G. and P.M.-M. conducted the necessary literature reviews and drafted the first manuscript. J.C.F.-G. provided critical feedback and helped shape the analysis and the manuscript. All the authors contributed towards the revision and writing of the final draft. All authors have read and agreed to the published version of the manuscript.

Funding: This research was funded by the "Researching in Sport Sciences" research group (CTS-563) of the Andalusian Research Plan.

Institutional Review Board Statement: The study was conducted according to the guidelines of the Declaration of Helsinki, and approved by Ethics Committee of University of Málaga (protocol code 65-2020-H and date of approval 30/09/2020).

Informed Consent Statement: Informed consent was obtained from all subjects involved in the study.

Data Availability Statement: Data consent was obtained from all subjects involved in the study.

Acknowledgments: We would like to thank Real Club Mediterraneo of Malaga, its rowing captain Juan Carlos Marfil Rodríguez and the team of the Malaga dragon boat BCS for opening their doors to us and helping us. 
Conflicts of Interest: The authors declare no conflict of interest.

Study Limitations: This is a pioneering study to understand the cardiac effects of rowing in BCS women. For this reason, there are certain limitations such as the absence of a control group, the use of tests such as spiroergometry, echocardiography or gas analysis.

\section{References}

1. World Health Organization. Breast Cancer: Prevention and Control. Available online: https://www.who.int/cancer/detection/ breastcancer/en/ (accessed on 14 June 2021).

2. International Agency for Research on Cancer (IARC) Cancer Today. Available online: https://gco.iarc.fr/today/home (accessed on 14 June 2021).

3. Parker, J.R.; Baradoy, G.; Katz, L. Using virtual reality technology and biometric interfaces in obesity reduction. Can. J. Diabetes 2011. [CrossRef]

4. Guinto-Adviento, M.L.; Zavala, M.A.O. "I am a complete woman”: Dragon boat and breast cancer survival. Rev. Psicol. Deporte 2017, 26, 12-16.

5. Cantarero-Villanueva, I.; Fernandez-Lao, C.; del Moral-Avila, R.; Fernandez-de-las-Penas, C.; Feriche-Fernandez-Castanys, M.B.; Arroyo-Morales, M. Effectiveness of Core Stability Exercises and Recovery Myofascial Release Massage on Fatigue in Breast Cancer Survivors: A Randomized Controlled Clinical Trial. Evid. Based Complement. Altern. Med. 2012, 620619. [CrossRef]

6. Anthis, N.J.; Kavanaugh-Lynch, M.H.E. The Global Challenge to Prevent Breast Cancer: Surfacing New Ideas to Accelerate Prevention Research. Int. J. Environ. Res. Public Health 2020, 17, 1394. [CrossRef]

7. Lope, V.; Martin, M.; Castello, A.; Casla, S.; Ruiz, A.; Baena-Canada, J.M.; Casas, A.M.; Calvo, L.; Bermejo, B.; Munoz, M.; et al. Physical activity and breast cancer risk by pathological subtype. Gynecol. Oncol. 2017, 144, 577-585. [CrossRef]

8. Mascherini, G.; Tosi, B.; Giannelli, C.; Grifoni, E.; Degl'Innocenti, S.; Galanti, G. Breast cancer: Effectiveness of a one-year unsupervised exercise program. J. Sports Med. Phys. Fitness 2019, 59, 283-289. [CrossRef] [PubMed]

9. Patsou, E.D.; Alexias, G.D.; Anagnostopoulos, F.G.; Karamouzis, M.V. Effects of physical activity on depressive symptoms during breast cancer survivorship: A meta-analysis of randomised control trials. ESMO Open 2017, 2, e000271. [CrossRef] [PubMed]

10. Panchik, D.; Masco, S.; Zinnikas, P.; Hillriegel, B.; Lauder, T.; Suttmann, E.; Chinchilli, V.; McBeth, M.; Hermann, W. Effect of Exercise on Breast Cancer-Related Lymphedema: What the Lymphatic Surgeon Needs to Know. J Reconstr. Microsurg. 2019, 35, 37-45. [CrossRef] [PubMed]

11. Pinto-Carral, A.; Molina, A.J.; de Pedro, Á.; Ayón, C. Pilates for women with breast cancer: A systematic review and meta-analysis. Complement. Ther. Med. 2018, 41, 130-140. [CrossRef]

12. Baumann, F.T.; Reike, A.; Reimer, V.; Schumann, M.; Hallek, M.; Taaffe, D.R.; Newton, R.U.; Galvao, D.A. Effects of physical exercise on breast cancer-related secondary lymphedema: A systematic review. Breast Cancer Res. Treat. 2018, 170, 1-13. [CrossRef]

13. Moros, M.T.; Ruidiaz, M.; Caballero, A.; Serrano, E.; Martinez, V.; Tres, A. Effects of an exercise training program on the quality of life of women with breast cancer on chemotherapy. Rev. Med. Chile 2010, 138, 715-722. [PubMed]

14. Lopez, V.A.Q.; Lopez, K.D.D.; Juvera, G.C. Interventions to improve healthy lifestyles and their effects on psychological variables among breast cancer survivors: A systematic review. Nutr. Hosp. 2018, 35, 979-992. [CrossRef]

15. Lahart, I.M.; Metsios, G.S.; Nevill, A.M.; Carmichael, A.R. Physical activity for women with breast cancer after adjuvant therapy. Cochrane Database Syst. Rev. 2018, 1, CD011292. [CrossRef]

16. Singh, B.; Spence, R.R.; Steele, M.L.; Sandler, C.X.; Peake, J.M.; Hayes, S.C. A Systematic Review and Meta-Analysis of the Safety, Feasibility, and Effect of Exercise in Women With Stage II plus Breast Cancer. Arch. Phys. Med. Rehabil. 2018, 99, 2621-2636. [CrossRef] [PubMed]

17. Hong, F.; Ye, W.; Kuo, C.H.; Zhang, Y.; Qian, Y.; Korivi, M. Exercise Intervention Improves Clinical Outcomes, but the “Time of Session" is Crucial for Better Quality of Life in Breast Cancer Survivors: A Systematic Review and Meta-Analysis. Cancers 2019, 11, 706. [CrossRef] [PubMed]

18. Di Blasio, A.; Morano, T.; Cianchetti, E.; Gallina, S.; Bucci, I.; Di Santo, S.; Tinari, C.; Di Donato, F.; Izzicupo, P.; Di Baldassarre, A.; et al. Psychophysical health status of breast cancer survivors and effects of 12 weeks of aerobic training. Complement. Ther. Clin. Pract. 2017, 27, 19-26. [CrossRef]

19. Dieli-Conwright, C.M.; Courneya, K.S.; Demark-Wahnefried, W.; Sami, N.; Lee, K.; Sweeney, F.C.; Stewart, C.; Buchanan, T.A.; Spicer, D.; Tripathy, D.; et al. Aerobic and resistance exercise improves physical fitness, bone health, and quality of life in overweight and obese breast cancer survivors: A randomized controlled trial. Breast Cancer Res. 2018, 20. [CrossRef]

20. Thomas, G.A.; Cartmel, B.; Harrigan, M.; Fiellin, M.; Capozza, S.; Zhou, Y.; Ercolano, E.; Gross, C.P.; Hershman, D.; Ligibel, J.; et al. The Effect of Exercise on Body Composition and Bone Mineral Density in Breast Cancer Survivors Taking Aromatase Inhibitors. Obesity 2017, 25, 346-351. [CrossRef] [PubMed]

21. Zhao, J.; Ma, Y.; Tanimoto, T.; Al, E. Effects of physical activity and stress on the relationship between social capital and quality of life among breast cancer survivors. Sci. Rep. 2020, 10, 17746. [CrossRef] [PubMed]

22. Grazioli, E.; Cerulli, C.; Dimauro, I.; Moretti, E.; Murri, A.; Parisi, A. 2020 New Strategy of Home-Based Exercise during Pandemic COVID-19 in Breast Cancer Patients: A Case Study. Sustainability 2020, 12, 6940. [CrossRef] 
23. Boyne, D.J.; O'Sullivan, D.E.; Olij, B.F.; King, W.D.; Friedenreich, C.M.; Brenner, D.R. Physical Activity, Global DNA Methylation, and Breast Cancer Risk: A Systematic Literature Review and Meta-analysis. Cancer Epidemiol. Biomark. Prev. 2018, 27, $1320-1331$. [CrossRef]

24. Falcetta, F.S.; Trasel, H.D.; de Almeida, F.K.; Falcetta, M.R.R.; Falavigna, M.; Rosa, D.D. Effects of physical exercise after treatment of early breast cancer: Systematic review and meta-analysis. Breast Cancer Res. Treat. 2018, 170, 455-476. [CrossRef]

25. Hardefeldt, P.J.; Penninkilampi, R.; Edirimanne, S.; Eslick, G.D. Physical Activity and Weight Loss Reduce the Risk of Breast Cancer: A Meta-analysis of 139 Prospective and Retrospective Studies. Clin. Breast Cancer 2018, 18, e601-e612. [CrossRef]

26. Chen, X.; Wang, Q.; Zhang, Y.; Xie, Q.; Tan, X. Physical Activity and Risk of Breast Cancer: A Meta-Analysis of 38 Cohort Studies in 45 Study Reports. Value Health 2019, 22, 104-128. [CrossRef]

27. Gernaat, S.A.M.; Ho, P.J.; Rijnberg, N.; Al, E. Risk of death from cardiovascular disease following breast cancer in Southeast Asia: A prospective cohort study. Sci. Rep. 2017, 7, 1365. [CrossRef] [PubMed]

28. Grimley, C.E.; Kato, P.M.; Grunfeld, E.A. Health and health belief factors associated with screening and help-seeking behaviours for breast cancer: A systematic review and meta-analysis of the European evidence. Br. J. Health Psychol. 2020, 25, 107-128. [CrossRef] [PubMed]

29. Abdin, S.; Lavallée, J.F.; Faulkner, J.; Husted, M. A systematic review of the effectiveness of physical activity interventions in adults with breast cancer by physical activity type and mode of participation. Psychooncology 2019, 28, 1381-1393. [CrossRef] [PubMed]

30. Chan, D.S.M.; Abar, L.; Cariolou, M.; Nanu, N.; Greenwood, D.C.; Bandera, E.V.; McTiernan, A.; Norat, T. World Cancer Research Fund International: Continuous Update Project-systematic literature review and meta-analysis of observational cohort studies on physical activity, sedentary behavior, adiposity, and weight change and breast cancer risk. Cancer Causes Control 2019, 30, 1183-1200. [CrossRef] [PubMed]

31. Leischik, R.; Dworrak, B.; Strauss, M.; Horlitz, M.; Pareja-Galeano, H.; de la Guía-Galipienso, F.; Lippi, G.; Lavie, C.J.; Perez, M.V.; Sanchis-Gomar, F. Special Article-Exercise-induced right ventricular injury or arrhythmogenic cardiomyopathy (ACM): The bright side and the dark side of the moon. Prog. Cardiovasc. Dis. 2020, 671-681. [CrossRef] [PubMed]

32. Spei, M.E.; Samoli, E.; Bravi, F.; La Vecchia, C.; Bamia, C.; Benetou, V. Physical activity in breast cancer survivors: A systematic review and meta-analysis on overall and breast cancer survival. Breast 2019, 44, 144-152. [CrossRef] [PubMed]

33. Schmitz, K.H.; Courneya, K.S.; Matthews, C.; Demark-Wahnefried, W.; Galvao, D.A.; Pinto, B.M.; Irwin, M.L.; Wolin, K.Y.; Segal, R.J.; Lucia, A.; et al. American College of Sports Medicine Roundtable on Exercise Guidelines for Cancer Survivors. Med. Sci. Sports Exerc. 2010, 42, 1409-1426. [CrossRef]

34. Parker, M.H.; Campbell, S.; Weinstein, A.A. Upper Extremity Exercise in Older Breast Cancer Survivors: Benefits of Dragon Boat Paddling. Curr. Geriatr. Rep. 2016, 5, 226-232. [CrossRef]

35. Mc Kenzie, D. Abreast in a boat-A race against breast cancer. CMAJ 1998, 159, 376-378.

36. Gavala-González, J. Las Especialidades del Piragüismo: Canoas Dragón o Dragon Boats; Universidad de Sevilla: Sevilla, Spain, 2019; ISBN 978-84-17337-83-4.

37. Fong, S.S.M.; Ng, S.S.M.; Luk, W.S.; Chung, J.W.Y.; Ho, J.S.C.; Ying, M.; Ma, A.W.W. Effects of Qigong Exercise on Upper Limb Lymphedema and Blood Flow in Survivors of Breast Cancer: A Pilot Study. Integr. Cancer Ther. 2014, 13, 54-61. [CrossRef] [PubMed]

38. McDonough, M.H.; Patterson, M.C.; Weisenbach, B.B.; Ullrich-French, S.; Sabiston, C.M. The difference is more than floating: Factors affecting breast cancer survivors' decisions to join and maintain participation in dragon boat teams and support groups. Disabil. Rehabil. 2019, 41, 1788-1796. [CrossRef] [PubMed]

39. Cina, I.; Di Sebastiano, K.; Faulkner, G. “One stroke, with twenty-two people”: Exploring prostate cancer survivors' participation in dragon boating. J. Psychosoc. Oncol. 2020. [CrossRef] [PubMed]

40. Fong, A.J.; Saxton, H.R.; Kauffeldt, K.D.; Sabiston, C.M.; Tomasone, J.R. "We're all in the same boat together": Exploring quality participation strategies in dragon boat teams for breast cancer survivors. Disabil. Rehabil. 2020, 1-12. [CrossRef] [PubMed]

41. Giganti, M.G.; Tresoldi, I.; Sorge, R.; Melchiorri, G.; Triossi, T.; Masuelli, L.; Lido, P.; Albonici, L.; Foti, C.; Modesti, A.; et al. Physical exercise modulates the level of serum MMP-2 and MMP-9 in patients with breast cancer. Oncol. Lett. 2016, 12, $2119-2126$. [CrossRef] [PubMed]

42. Melchiorri, G.; Viero, V.; Triossi, T.; Sorge, R.; Tancredi, V.; Cafaro, D.; Andreis, C.; Vulpiani, M.C.; Saraceni, V.M. New approach to evaluate late arm impairment and effects of dragon boat activity in breast cancer survivors. Medicine 2017, 96. [CrossRef]

43. Mitchell, T.L.; Yakiwchuk, C.V.; Griffin, K.L.; Gray, R.E.; Fitch, M.I. Survivor dragon boating: A vehicle to reclaim and enhance life after treatment for breast cancer. Health Care Women Int. 2007, 28, 122-140. [CrossRef] [PubMed]

44. Sabiston, C.M.; McDonough, M.H.; Crocker, P.R.E. Psychosocial experiences of breast cancer survivors involved in a dragon boat program: Exploring links to positive psychological growth. J. Sport Exerc. Psychol. 2007, 29, 419-438. [CrossRef] [PubMed]

45. Romero-Barquero, C.E. Actividad física en el tiempo libre previene enfermedades cardiacas/cardiovasculares: Una revisión sistemática. Rev. Iberoam. Cienc. Act. Física Deporte 2020, 9, 1-22. [CrossRef]

46. Marriott, H.E.; Lamb, K.L. The use of ratings of perceived exertion for regulating exercise levels in rowing ergometry. Eur. J. Appl. Physiol. Occup. Physiol. 1996, 72, 267-271. [CrossRef] [PubMed]

47. Das, A.; Mandal, M.; Syamal, A.K.; Majumdar, P. Monitoring Changes of Cardio-Respiratory Parameters During $2000 \mathrm{~m}$ Rowing Performance. Int. J. Exerc. Sci. 2019, 12, 483-490. 
48. Yoshiga, C.C.; Higuchi, M. Rowing performance of female and male rowers. Scand. J. Med. Sci. Sports 2003, 13, 317-321. [CrossRef] [PubMed]

49. Aramendi, J.M. Remo olímpico y remo tradicional: Aspectos biomecánicos, fisiológicos y nutricionales. Arch. Med. Deporte 2014, $31,51-59$.

50. Instituto Nacional del Cáncer Problemas Cardíacos: Investigación de Los Efectos Secundarios Cardíacos de Tratamientos del Cáncer. Available online: https:/ / www.cancer.gov/espanol/noticias/temas-y-relatos-blog/2018/cancer-tratamiento-corazonefectos-secundarios (accessed on 14 June 2021).

51. Stefani, L.; Galanti, G.; Di Tante, V.; Klika, R.J.; Maffulli, N. Dragon Boat training exerts a positive effect on myocardial function in breast cancer survivors. Phys. Sportsmed. 2015, 43, 307-311. [CrossRef] [PubMed]

52. Serra, M.C.; Ryan, A.S.; Ortmeyer, H.K.; Addison, O.; Goldberg, A.P. Resistance training reduces inflammation and fatigue and improves physical function in older breast cancer survivors. Menopause 2018, 25, 211-216. [CrossRef] [PubMed]

53. Anderson, C.; Nichols, H.B.; Deal, A.M.; Park, Y.M.M.; Sandler, D.P. Changes in cardiovascular disease risk and risk factors among women with and without breast cancer. Cancer 2018, 124, 4512-4519. [CrossRef]

54. Jones, L.M.; Stoner, L.; Brown, C.; Baldi, J.C.; McLaren, B. Cardiorespiratory fitness predicts cardiovascular health in breast cancer survivors, independent of body composition, age and time post-treatment completion. Breast Cancer 2019, 26, 729-737. [CrossRef]

55. van den Bogaard, V.A.B.; van Luijk, P.; Hummel, Y.M.; van der Meer, P.; Schuit, E.; Boerman, L.M.; Maas, S.; Nauta, J.F.; Steggink, L.C.; Gietema, J.A.; et al. Cardiac Function After Radiation Therapy for Breast Cancer. Int. J. Radiat. Oncol. Biol. Phys. 2019, 104, 392-400. [CrossRef] [PubMed]

56. Lee, M.K.; Lee, D.H.; Park, S.; Kim, S.I.; Jeon, J.Y. Relationship between resting heart rate and metabolic risk factors in breast cancer patients. Clin. Chim. Acta 2018, 486, 104-109. [CrossRef] [PubMed]

57. Harriss, D.J.; Macsween, A.; Atkinson, G. Standards for Ethics in Sport and Exercise Science Research: 2018 Update. Int. J. Sports Med. 2017, 38, 1126-1131. [CrossRef] [PubMed]

58. Review, C.; Communication, S.; Principles, G. World Medical Association Declaration of Helsinki: Ethical principles for medical research involving human subjects. J. Am. Coll. Dent. 2014, 81, 14-18. [CrossRef]

59. Cote, C.G.; Casanova, C.; Marin, J.M.; Lopez, M.V.; Pinto-Plata, V.; de Oca, M.M.; Dordelly, L.J.; Nekach, H.; Celli, B.R. Validation and comparison of reference equations for the 6-min walk distance test. Eur. Respir. J. 2008, 31, 571-578. [CrossRef]

60. Gavala-González, J. Las Modalidades del Remo: El Remo en banco Fijo; de Sevilla, U., Ed.; Sevilla, Spain, 2018; Available online: https: / / ra.sav.us.es/ (accessed on 14 June 2021).

61. Börg, G. Psychophysical bases of perceived exertion. Med. Sci. Sports Exerc. 1982, 14, 377-381. [CrossRef] [PubMed] 